\title{
Pengendalian Internal Penerimaan Negara Bukan Pajak di Taman Nasional Bali Barat
}

\author{
(Internal Control of Non-Tax State Revenue In The Bali Barat National Park)
}

\author{
Rakhmah Budi*, Nur Handayani \\ Jurusan Akuntansi, Fakultas Ekonomi dan Bisnis, Universitas Jember (UNEJ) \\ Jln. Kalimantan 37, Jember 68121 \\ E-mail:Rakhmah_budi@yahoo.com
}

\begin{abstract}
Abstrak
Tujuan penelitian ini adalah untuk mengetahui bagaimana pengendalian internal bagi Penerimaan Negara Bukan Pajak (PNBP) di Taman Nasional Bali Barat (TNBB) yang ditinjau dari sisi keakuratan pencatatan, kepatuhan pengelolaan, serta tingkat keefektifan kebijakan PNBP di Taman Nasional Bali Barat. Penelitian ini adalah penelitian deskriptif kualitatif. Metode analisis yang digunakan adalah triangulasi teknik. Berdasarkan hasil penelitian dapat diambil kesimpulan bahwa PP No. 12 Tahun 2014 menjadi alat pengendalian internal terhadap PNBP di Taman Nasional Bali Barat. Keakuratan pencatatn PNBP di TNBB didasarkan pada penetapan tarif PP No. 12 Tahun 2014 tentang Tarif atas Jenis PNBP yang Berlaku pada Kementerian Kehutanan. Untuk kepatatuhan pengelolaan PNBP di TNBB didasarkan pada PP No. 20 Tahun 1997 tentang PNBP. Kemudian untuk tingkat keefektifan PNBP di TNBB, dengan perolehan persentase diatas $100 \%$ pada setiap tahunnya, berdasarkan standarisasi disimpulkan bahwa dalam lima tahun tersebut PNBP di TNBB sangat efektif.
\end{abstract}

Kata kunci: Pengendalian Internal, Penerimaan Negara Bukan Pajak, dan Pengelolaan Keuangan Negara

\begin{abstract}
This study aims to know the internal control of non-tax state revenues in Bali Barat National Park in terms of accuracy of recording, staffing, and the effectiveness of non-tax state revenue policy in Bali Barat National Park. This research is qualitative descriptive research. The method of analysis used in this research is triangulation technique. Based on the results of the study, it can be taken several provisions of Government Regulation No. 12 of 2014 to become a tool of internal control of non-tax state revenue in Bali Barat National Park. The accuracy of recording of non-tax state revenue in Bali Barat National Park at the tariff level based on Government Regulation No. 12 of 2014 on Tariff of Non-Tax State Revenue applicable to the Ministry of Forestry. For Non-Tax State Revenue Receiver in Bali Barat National Park on Government Regulation No. 20/1997 on Non-Tax State Revenues. Then for the level of effectiveness of Non-Tax State Revenue in Bali Barat National Park, with the title effectiveness above 100\% in every year, not the standard in Bali BaratNational Park is very effective.
\end{abstract}

Keywords: Internal control, Non-Tax State Revenue, and Management of government finances

\section{Pendahuluan}

Terselenggaranya Pemerintahan yang baik merupakan prasyarat bagi pemerintahan dalam mewujudkan aspirasi masyarakat dan mencapai cita-cita bangsa dan negara. Untuk itu diperlukan penerapan sistem pertanggungjawaban yang terukur, sehingga penyelengaraan pemerintah dan pembangunan berlangsung secara berdaya guna, berhasil guna, bersih, dan bertanggung jawab serta bebas dari budaya korupsi, kolusi, dan nepotisme.Upaya pengembangan tersebut sejalan dengan dan didasarkan pada TAP MPR RI Nomor XI/MPR/1998 tentang Penyelenggara Negara yang Bersih dan Bebas Korupsi, Kolusi, dan Nepotisme, dan Undang-Undang (UU) No. 28 Tahun 1999 tentang Penyelenggara Negara yang Bersih dan Bebas dari Korupsi, Kolusi, dan Nepotisme (KKN). Pasal 3 Undang-Undang Nomor 28 Tahun 1999 tersebut menyatakan bahwa asas-asas umum penyelenggaraan negara meliputi asas kepastian hukum, asas tertib penyelenggaraan kepentingan umum, asas keterbukaan, asas proporsionalitas, asas profesionalitas, dan asas akuntabilitas. Asas-asas umum tersebut diperlukan guna menjamin terselenggaranya pelaporan pertanggungjawaban Keuangan Negara yang terpercaya. Salah satu upaya untuk mewujudkan transparansi dan akuntabilitas Keuangan Negara berdasarkan UU Nomor 17 Tahun 2003 adalah dengan melaksanakan laporan pertanggungjawaban keuangan pemerintah yang memenuhi prinsip-prinsip tepat waktu dan disusun dengan mengikuti Standar Akuntansi Pemerintah yang telah diterima secara umum. Pengawasan terhadap pelaksanaan anggaran yang sesuai dengan perencanaan dan peraturan merupakan hal yang diperlukan, Adapun yang menjadi obyek dari kegiatan pengawasan adalah adanya kemungkinan terjadinya kesalahan, penyimpangan, kecurangan, pelanggaran serta guna mewujudkan tertib secara administratif.

Dalam pelaporan keuangan negara yang tercantum pada pasal 3 UU Nomor 17 Tahun 2003 menjelaskan bahwa "Keuangan Negara dikelola secara tertib, taat pada peraturan perundangundangan, efisien, ekonomis, efektif, transparan, dan bertanggung jawab dengan memperhatikan rasa keadilan dan kepatutan". Begitupun sama halnya dengan pelaporan pengelolaan PNBP mengacu pada UU Nomor 17 Tahun 2003 tersebut dengan menerapkan prinsip transparansi dan akuntabilitas. Pengelolaan PNBP pada pasal 5 UU Nomor 20 Tahun 1997 tentang Penerimaan Negara Bukan Pajak menyebutkan "Seluruh Penerimaan Negara Bukan Pajak dikelola dalam sistem Anggaran Pendapatan dan Belanja

\footnotetext{
* Coressponding Author
} 
Negara".

Sebagaimana yang diketahui bahwa penerimaan negara terbesar berasal dari pajak, namun selain penerimaan pajak ada pula penerimaan yang bukan berasal dari pajak yang memberikan kontribusi cukup besar, penerimaan tersebut disebut dengan Penerimaan Negara Bukan Pajak (PNBP). Menurut UU No. 20 Tahun 1997 tentang Penerimaan Negara Bukan Pajak, bahwa penerimaan Negara bukan pajak adalah seluruh penerimaan pemerintah pusat yang tidak berasal dari penerimaan perpajakan.

Dalam hal ini Kementerian Kehutanan mendapatkan manfaat hutan yang sebesar-besarnya secara serbaguna dan lestari baik secara langsung maupun tidak lagsung bagi kemakmuran masyarakat, hal tersebut sebagaimana tertera pada pasal 17 PP No. 6 Tahun 2007 tentang Pemanfaatan Hutan. Dengan begitu untuk menjadikan pemerintahan yang baik, pengelolaan Sumber Daya Alam (SDA)maupun publik khususnya pengelolaan keuangan harus dilakukan pemerintah secara berdaya guna, berhasil guna, bersih, dan bertanggung jawab serta bebas. Sebagai bentuk dari pertanggungjawaban kepada publik atas anggaran yang diterima dan pengelolaan hasil pemanfaatan Sumber Daya Alam (SDA), setiap pemerintahan/lembaga diwajibkan untuk menyusun laporan keuangan yang mana menerapkan asas akuntabilitas dan transparansi untuk mencegah adanya kesalahan administratif. Hal ini sebagaimana dimuat dalam Undang - Undang Nomor 17 Tahun 2003 tentang Keuangan Negara, pasal 9 huruf (e) yang terkait dengan tugas-tugas Kementerian Negara/ Lembaga sebagai penggunaanggaran/ barang. Pengelolaan Penerimaan Bukan Pajak di Kementerian Kehutanan dapat mengacu pada UU Nomor 17 Tahun 2003 tentang Keuangan Negara.

Taman Nasional Bali Barat merupakan Instansi Pemerintah yang dibawahi oleh Kementerian Lingkungan Hidup dan Kehutanan yang mana setiap aktivitas keuangan berdasarkan Undang-Undang Nomor 17 Tahun 2003 tentang Keuangan Negara harus dipertanggungjawabkan, termasuk pengelolaan Penerimaan Negara Bukan Pajak (PNBP). Saat ini Taman Nasional Bali Barat mempunyai tiga perusahaan yang sudah mendapatkan izin Pengusahaan Pariwisata Alam (IPPA) seperti, PT Shorea Barito Wisata dan PT Trimbawan Swastama Sejati (Penyediaan Resort dengan wisata alam sebagai atraksi wisata) dan PT Disthi Kumala Bahari (Pengusahaan pariwisata alam dengan pengakaran mutiara sebagai atraksi wisata). Sebagai objek wisata, Taman Nasional Bali Barat mempunyai nilai dari sisi kawasan wisata yaitu Nilai Manfaat Wisata. Dengan adanya potensi tersebut memungkinkan Taman Nasional Bali Barat untuk lebih mengoptimalkan perolehan Penerimaan Negara Bukan Pajak (PNBP). Adapun besaran Penerimaan Negara Bukan Pajak (PNBP) Taman Nasional Bali Barat pada tahun 2012, 2013, 2014, 2015, 2016 berdasarkan informasi yang diperoleh dari Taman Nasional Bali Barat yaitu sebesar Rp. 439.653.500, Rp. 761.069.000, Rp. 1.540.807.500, Rp. 7.049.300.000, Rp. 9.294.537.000. Besaran Penerimaan Negara Bukan Pajak (PNBP) Taman Nasional Bali Barat tersebut menunjukkan peningkatan perolehan PNBP dari tahun ke tahun.

Oleh karena keberagaman jenis Penerimaan Negara Bukan Pajak (PNBP) di departemen dan non departemen pemerintah, maka masing-masing departemen dan lembaga non departemen membutuhkan suatu Peraturan Pemerintah untuk kepentingan lembaganya. Untuk menunjang pembangunan nasional serta mengoptimalkan Penerimaan Negara Bukan Pajak (PNBP) pada Kementerian Kehutanan, maka ditetapkan suatu Pertaturan Pemerintah yang mengatur PNBP yang berlaku pada Kementerian Kehutanan yaitu Peraturan Pemrintah Nomor 12 tahun 2014. Keberadaan PP No. 12 tahun 2014 mengatur tentang tarif atas jenis PNBP yang berlaku di Kementerian Kehutanan. Oleh karena itu peraturan ini membutuhkan pelaksanaan di lingkungan Kementerian Kehutanan itu sendiri, sehingga peraturan tersebut dapat menjadi cotrolling bagi PNBP di lingkungan Kementerian Kehutanan.

Menurut hasil penelitian dari Sijabat (2009) tentang Pengendalian Internal Terhadap Penerimaan Negara Bukan Pajak (PNBP) Melalui Penerapan Peraturan Pemerintah Republik Indonesia Nomor 46 Tahun 2002 Pada Kantor Wilayah Badan Pertanahan Nasional (BPN) Sumatera Utara, PP nomor 46 Tahun 2002 menjadi alat pengendali internal terhadap PNBP di lingkungan Kanwil BPN Sumatera Utara. Kemudian penelitian oleh Natalia (2012) tentang Pengendalian Internal Terhadap Penerimaan Negara Bukan Pajak (PNBP) Melalui Penerapan Peraturan Pemerintah No 9 Tahun 2012 pada Direktorat Jenderal Mineral dan Batu Bara Jakarata, Jumlah penerimaan menggambarkan keefektifan kebijakan PNBP melalui perbandingan realisasi penerimaan dan target penerimaan. Pada tahun 2011 penerimaan iuran tetap tidak mencapai target yang menunjukan bahwa kinerja pencapaian target kurang, namun ditahun 2009 dan 2010 pencapaian target tercapai, dan penerimaan iuran royalty dari tahun 2009 - 2011 pencapaian target selalu tercapai bahkan melebihi target yang dianggarkan yang berarti keefektifan kebijakan di Direktorat Jenderal Mineral dan Batubara sangat baik dan konsistensi pun tercapai. Selain itu penelitian dari Yuliyanti (2014) tentang Analisis Efektivitas dan Kontribusi Pendapatan Negara Bukan Pajak (PNBP) Pada Fakultas di Universitas Bengkulu, tingkat efektivitas realisasi PNBP pada Unit kerja di Universitas Bengkulu secara keseluruhan selama lima tahun berada pada kondisi Sangat Efektif. Kemudian untuk tingkat kontribusi PNBP seluruh Unit kerja selama lima tahun, kontribusi terbesar adalah dari Fakultas KIP, yang kemudian disusul oleh Rektorat, terus Fakultas Kedokteran, dan Fakultas Ekonomi, Unit kerja ini mampu memberikan kontribusi PNBP masing-masing mendekati 20\%. Kontribusi PNBP selanjutnya dibawah $10 \%$ diberikan oleh Fakultas Pertanian, Fakultas ISIP, Fakultas Hukum, Fakultas Teknik, dan Fakultas MIPA.

Rumusan masalah dalam penelitian ini diantaranya yaitu bagaimana keakuratan pencatatan Penerimaan Negara Bukan Pajak (PNBP) di Taman Nasional Bali Barat, bagaimana kepatuhan pengelolaan Penerimaan Negara Bukan Pajak (PNBP) di Taman Nasional Bali Barat, dan bagaimana tingkat keefektifan kebijakan Penerimaan Negara Bukan Pajak (PNBP) di Taman Nasional Bali Barat. hal ini bertujuan untuk mengetahui keakuratan pencatatan tarif Penerimaan Negara Bukan Pajak (PNBP) di Taman Nasional Bali Barat berdasarkan Peraturan Pemerintah Nomor 12 Tahun 2014 Tentang Tarif atas Jenis PNBP yang berlaku pada Kementerian Kehutanan, serta Untuk mengetahui kepatuhan pengelolaan Penerimaan Negara Bukan Pajak (PNBP) di 
Taman Nasional Bali Barat.

\section{Metode}

\section{Rancangan Penelitian}

Penelitian ini menggunakan metode deskriptif kualitatif. Menurut Sanusi (2011:13), desain penelitian deskriptif adalah desain penelitian yang disusun dalam rangka memberikan gambaran secara sistematis tentang informasi ilmiah yang berasal dari subyek atau obyek penelitian. Metode penelitian kualitatif tidak menggunakan generalisasi tetapi lebih menekankan pada kedalaman informasi sehingga sampai pada tingkat makna (Sugiyono, 2012: 9).

\section{Jenis dan Sumber Data}

Jenis data yang digunakan dalam penelitian ini adalah data primer dan data sekunder. Sumber data dalam penelitian ini adalah laporan keuangan serta laporan kegiatan/aktivitas yang menghasilkan Penerimaan Negara Bukan Pajak (PNBP) di Taman Nasional Bali Barat dan peneliti melakukan wawancara kepada informan baik itu dari pihak Kepala Sub Bagian Tata Usaha, dan Bendahara Penerima di Taman Nasional Bali Barat.

\section{Metode Pengumpulan Data}

Pengumpulan data primer dengan melakukan wawancara terstruktur. wawancara terstruktur menurut Esterberg, dalam Sugiyono (2012:233) yaitu peneliti telah mengetahui dengan pasti informasi apa yang akan diperoleh sehingga peneliti menyiapkan instrumen penelitian berupa pertanyaan tertulis yang alternatif jawabannya pun telah disiapkan. Lebih lanjut wawancara kepada informan baik itu dari pihak Kepala Sub Bagian Tata Usaha, dan bendahara penerima di Taman Nasional Bali Barat. Sedangkan peneliti mengumpulan data sekunder dengan menelaah dokumen-dokumen terkait dengan pengelolaan Penerimaan Negara Bukan Pajak (PNBP) dalam bentuk laporan keuangan serta laporan kegiatan/aktivitas yang menghasilkan Penerimaan Negara Bukan Pajak di Taman Nasional Bali Barat.

\section{Metode Analisis Data}

Metode analisis data dalam penelitian ini dilakukan dengan menggunakan triangulasi teknik, yaitu untuk menguji kredibilitas data dilakukan dengan cara mengecek data kepada sumber yang sama dengan teknik yang berbeda. Jadi, triangulasi yang dilakukan dalam penelitian ini yaitu membandingkan hasil data dari dokumen yang diperoleh dengan wawancara mengenai pengelolaan Penerimaan Negara Bukan Pajak yang dilakukan dengan pihak terkait.

\section{Hasil dan Pembahasan}

\section{Hasil}

\section{Keakuratan Pencatatan PNBP di Taman Nasional Bali Barat}

Pencatatan tarif dari kegiatan yang menghasilkan PNBP sudah didasarkan pada petepan tarif yang telah ditetapkan untuk setiap kegiatan yang berada di Taman Nasional Bali Barat, sehingga tarif yang dikenakan untuk setiap jenis kegiatan yang menghasilkan PNBP di Taman Nasional Bali Barat telah memiliki dasar ketetapan. Penetapan tarif untuk setiap kegiatan atau jenis yang menghasilkan PNBP di Taman
Nasional Bali Barat berdasarkan pada Peraturan Pemerintah Nomor 12 Tahun 2014. Adapun untuk jenis PNBP yang dihasilkan di Taman Nasional Bali Barat, yaitu hanya berupa Penerimaan Pemanfaatan Jasa Lingkungan.

Penerimaan Pemanfaatan Jasa Lingkungan di Taman Nasional Bali Barat terdiri dari sub-sub jenis, yaitu Penerimaan Pariwisata Alam yang berupa karcis masuk pengunjung (Mancanegara dan Nusantara), pakir kendaraan. Selain itu terdapat pula sub jenis Penerimaan Pemanfaatan Jasa Lingkungan lainnya, yaitu Pungutan Jasa Kegiatan Wisata Alam (Mancanegara dan Nusantara) yang meliputi kegiatan tracking, pengamatan hidupan liar, diving, snorkeling, berkemah, penelitian, pengambilan snap shoot, pengambilan sampel tanaman, jasa transportasi. Namun untuk beberapa jenis PNBP Taman Nasional Rayon II berdasarkan Peraturan Pemerintah No. 12 Tahun 2014 masih belum bisa dijalankan dan diterapkan di Taman Nasional Bali Barat, seperti karcis masuk sepeda gayung, karcis masuk kendaraan roda 6 , karcis masuk kuda, parkir kapal motor dan kapal pesiar.

\section{Kepatuhan Pengelolaan Penerimaan Negara Bukan Pajak (PNBP) diTaman Nasional Bali Barat}

Untuk kepatuhan dari pengelolaan PNBP di Taman Nasional Bali Barat, penelitian difokuskan pada ketaatan Taman Nasional Bali Barat pada peraturan-peraturan yang berlaku. Kepatuhan Bendahara Penerima terhadap penyetoran Penerimaan Negara Bukan Pajak (PNBP) didasarkan pada UU No. 20 Tahun 1997 pasal 4 Tentang PNBP, yang menjelaskan "Seluruh Penerimaan Negara Bukan Pajak wajib disetor langsung secepatnya ke Kas Negara". Begitupun dalam PP No. 12 Tahun 2014 lebih lanjut diatur mengenai Penerimaan Negara Bukan Pajak (PNBP) pada Kementerian Kehutanan yang terdapat penjelasan pada pasal 6 yang berbunyi "Seluruh Penerimaan Negara Bukan Pajak yang berlaku pada Kementerian Kehutanan, wajib disetor langsung secepatnya ke Kas Negara". Adapun untuk pencairan dana PNBP oleh Taman Nasional Bali barat dilakukan dengan melakukan penyetoran PNBP secara keseluruhan (100\%) ke Kas Negara melalui Bank Pemerintah. Dana PNBP kemudian cair melalui DIPA yaitu yang terdiri dari dana murni dan dana PNBP. Sedangkan dalam hal ini sebagian dana PNBP di gunakan untuk kegiatan teknis Taman Nasional Bali Barat.

Berdasarkan DIPA Balai Taman Nasional Bali Barat, Ditjen. KSDAE Kementerian Lingkungan Hidup dan Kehutanan Tahun 2015, kegiatan teknis Taman Nasional Bali Barat yang di danai oleh sebagian dana PNBP meliputi: (1) penyusunan dokumen penataan zona; (2) penyusunan rencana pengelolaan; (3) pra kondisi dan perencanaan; (4) pembinaan daerah penyangga kawasan konservasi; (5) inventarisasi dan pemetaan sebaran satwa liar; (6) monitoring populasi satwa liar; (7) pembinaan habitat satwa liar; (8) pembinaan populasi satwa liar; (9) pembentukan unit khusus penyelamatan satwa terancam punah; (10) monitoring dan pengawasan IPPA; (11) analisa kebutuhan pengembangan pariwisata alam; (12) Informasi dan promosi; (13) peningkatan kapasitas SDM (Sumber Daya Manusia) pengelola wisata dan PNBP; (14) monitoring dan evaluasi; (15) koordinasi dan konsultasi; (16) pembinaan kader konservasi; (17) patroli pengamanan hutan; (18) penyegaran polhut dan PPNS; (19) deteksi dan peringatan dini; (20) kesiapsiagaan dan peningkatan 
koordinasi; (21) penyadartahuan dan promosi pencegahan kebakaran hutan; (22) pengembangan SARPRAS pengendalian kebakaran hutan; (23) pemadaman dan penanganan pasca kebakaran hutan; (24) evaluasi dan pelaporan; (25) data dan informasi; (26) administrasi kepegawaia; (27) perlengkapan. Macam-macam kegiatan teknis Taman Nasional Bali Barat tersebut memberikan penjelasan mengenai kegiatan apa saja yang dibiayai oleh sebagian dana PNBP.

\section{Tingkat keefektifan kebijakan PNBP di Taman Nasional Bali Barat}

Target dan realisasi PNBP Balai Taman Nasional Bali Barat dalam lima tahun, yaitu tahun 2012 s.d 2016 sebagai berikut:

Tabel 1. Target dan Realisasi PNBP Taman Nasional Bali Barat Tahun 2012, 2013, 2014, 2015, 2016

\begin{tabular}{crr}
\hline Tahun & Target $(\mathrm{Rp})$ & Realisasi $(\mathrm{Rp})$ \\
\hline 2012 & 400.450 .000 & $439,653,500$ \\
2013 & 468.162 .000 & $761,069,000$ \\
2014 & 943.413 .400 & $1,540,807,500$ \\
2015 & 531.875 .000 & $7,049,300,000$ \\
2016 & 3.500 .000 .000 & $9,294,537,000$ \\
\hline
\end{tabular}

Sumber: Statistik Balai Taman Nasional Bali Barat Tahun

2015 (Data diolah)

Untuk melihat tingkat keefektifan kebijakan Penerimaan Negara Bukan Pajak (PNBP) di Taman Nasional Bali Barat, formulasi yang digunakan adalah sebagai berikut (Agus, 2004; Yuliyanti, 2014):

Efektivitas $=$ Realisasi Penerimaan $\times 100 \%$

Target Penerimaan

Dapat dihitung persentase perbandingan antara realisasi dan target Penerimaan Negara Bukan Pajak (PNBP) untuk kegiatan-kegiatan yang menghasilkan PNBP di Taman Nasional Bali Barat, sebagai berikut:

Tabel 2. Laporan Realisasi, Target dan Efektifitas PNBP di Taman Nasional Bali Barat tahun 2012, 2013, 2014, 2015, 2016

\begin{tabular}{lccccc}
\hline Uraian & $\mathbf{2 0 1 2}$ & $\mathbf{2 0 1 3}$ & $\mathbf{2 0 1 4}$ & $\mathbf{2 0 1 5}$ & $\mathbf{2 0 1 6}$ \\
\hline Total & 439.65 & 761.069. & 1.540 .807 & 7.049 .300$. & 9.294 .537 .0 \\
Realisas & 3.500 & 000 & .500 & 000 & 00 \\
$\mathrm{i}$ & & & & & \\
Target & 400.45 & 468.162. & 943.413 .4 & 531.875 .0 & 3.500 .000 .0 \\
& 0.000 & 000 & 00 & 00 & 00 \\
Selisih & 39.203. & 292.907. & 597.394 .1 & 6.517 .425$. & 5.794 .537 .0 \\
& 500 & 000 & 00 & 000 & 00 \\
$\%$ & 109 & 162 & 163 & 1325 & 265 \\
Keefekti & & & & & \\
fan & & & & &
\end{tabular}

Sumber: Statistik Balai Taman Nasional Bali Barat Tahun 2015 (Data diolah)

Untuk mengukur efektif tidaknya Penerimaan Negara Bukan Pajak (PNBP) untuk lima tahun tersebut di Taman Nasional Bali Barat, maka digunakan standarisasi yang ditetapkan Departemen Dalam Negeri adalah sebagai berikut (Syamni, 2008; Yuliyanti, 2014):

- Hasil yang diperoleh berada diantara $<60 \%=$ tidak efektif
- Hasil yang diperoleh berada diantara $>60 \%-80 \%=$ cukup efektif

- Hasil yang diperoleh berada diantara $>80 \%-100 \%=$ efektif

- Hasil yang diperoleh berada diantara $>100 \%=$ sangat efektif

Berdasarkan tabel di atas maka dapat dilihat bahwa persentase Penerimaan Negara Bukan Pajak (PNBP) pada tahun 2012 tingkat keefektifannya sebesar 109\%. Kemudian di tahun 2013 tingkat keefektifan sebesar 162\%, pada tahun 2014 keefektifan 163\%. Di tahun 2015 terjadi peningkatan yang signifikan dibandingkan tahun-tahun sebelumnya, hal ini tampak dari kenaikan tingkat keefektifan menjadi 1325\% dan bahkan jauh melebihi target yang telah ditentukan. Pada tahun 2016 tingkat keefektifan sebesar 265\%. Dengan perolehan persentase keefektifan lebih dari $100 \%$ pada setiap tahunnya, berdasarkan standarisasidiatas dapat disimpulkan bahwa dalam lima tahun tersebut Penerimaan Negara Bukan Pajak (PNBP) di Taman Nasional Bali Barat sangat efektif.

\section{Pembahasan}

\section{Keakuratan Pencatatan PNBP di Taman Nasional Bali Barat}

Penetapan tarif Penerimaan Pemanfaatan Jasa Lingkungan di Taman Nasional Bali Barat menunjukkan kesesuian dengan Peraturan Pemerintah Nomor 12 Tahun 2014 yang mana berdasarkan pada Jenis dan Tarif PNBP Taman Nasional Rayon II. Sebagai contoh pengenaan tarif karcis masuk untuk pengunjung Mancanegara dilihat dari Laporan Penerimaan dan Penyetoran Pungutan Masuk di Taman Nasional Bali Barat bulan Desember 2016, pengenaan tarifnya sebesar Rp.200.000 (per orang). Sedangkan kegiatan Menyelam (Diving) untuk umum pengenaan tarifnya Rp.25.000 (per orang). Dengan jumlah pengunjung sebanyak 600 orang untuk kegiatan Menyelam (Diving) pada bulan Desember 2016, maka terakumulasi menjadi Rp. 15.000.000.

Adapun untuk beberapa jenis PNBP Taman Nasional Rayon II yang masih belum bisa dijalankan, hal ini karena terdapat beberapa jenis atau kegiatan yang menghasilkan PNBP tidak tersedia serta tidak memungkinkan diterapkan di Taman Nasional Bali Barat. Namun terdapat pula beberapa jenis atau kegiatan yang menghasilkan PNBP belum bisa diterapakan karena beberapa hal, seperti belum bisa dijalankan pungutan untuk parkir kapal motor, parkir kapal pesiar, karcis masuk untuk sepeda gayung, kuda, dan kendaraan roda 6. Belum bisa diterapkannya pungutan untuk jenis-jenis tersebut dikarenakan dalam memungut atau mengenakan tarif untuk karcis, seperti parkir roda 6 tidak semua pengunjung bersedia membayar karena telah membayar untuk karcis masuk kawasan.

\section{Kepatuhan Pengelolaan Penerimaan Negara Bukan Pajak (PNBP) di Taman Nasional Bali Barat}

Penyetoran PNBP oleh bendahara penerima Taman Nasional Bali Barat ke Kas Negara dilakukan seminggu sekali melalui Bank Pemerintah yang telah ditunjuk dengan menggunakan formulir Surat Setor Bukan Pajak (SSBP), kemudian bendahara penerima setelah melakukan penyetoran ke Bank selanjutnya bendahara penerima menerima Tanda Bukti Setor atau struk dari Bank serta menerima Bukti Penerimaan 
Negara (BPN) yang nantinya akan dikirim oleh bendahara penerima ke akun Simponi dan email. Sedangkan dalam hal pelaporan realisasi PNBP, pihak bendahara penerima Taman Nasional Bali Barat melaporkan setiap sebulan sekali.

Adapun penetapan persentase maupun jumlah PNBP yang diterima oleh Taman Nasional Bali Barat tidak ditentukan dan tidak adanya aturan yang ditetapkan oleh pemerintah pusat dalam hal ini Kementerian Lingkungan Hidup dan Kehutanan berapa besaran minimal dan maksimal yang dapat diterima oleh pihak Taman Nasional Bali Barat. Penerimaan dana PNBP di Taman Nasional Bali Barat tidak disesuaikan atau bergantung pada tingkat pendapatan PNBP yang diperoleh, sehingga tidak bergantung pada besaran PNBP yang dihasilkan dengan dana PNBP yang dapat dicairkan. Dalam hal ini besarnya sebagian dana PNBP yang dapat digunakan untuk kegiatan tertentu yang berkaitan dengan jenis PNBP ditetapkan oleh Menteri Keuangan.

Sedangkan kegiatan-kegiatan Taman Nasional Bali Barat yang menggunakan atau dibiayai sebagian dana PNBP, seperti pelaksanaan kegiatan teknis oleh Taman Nasional Bali Barat tersebut telah sesuai dengan Peraturan Pemerintah yang mengatur penggunaan sebagian dana PNBP. Berdasarkan yang telah tercantum dalam pasal 8 Peraturan Pemerintah Nomor 73 Tahun 1999 Tentang Tatacara Penggunaan Penerimaan Negara Bukan Pajak, sebagian dana PNBP dapat digunakan untuk menyelenggarakan kegiatan tertentu pada satuan kerja bersangkutan, yaitu dalam rangka pembiayaan operasional dana pembiayaan dan atau investasi, termasuk peningkatan kualitas sumber daya manusia.

\section{Tingkat keefektifan kebijakan PNBP di Taman Nasional Bali Barat}

Hasil penelitian menunjukkan bahwa adanya peningkatan jumlah PNBP dari tahun ke tahunnya di Taman Nasional Bali barat. Adanya peningkatan jumlah PNBP dari tahun 2012 s.d 2016 tersebut menunjukkan kinerja yang sangat baik dari pihak TNBB dalam mengoptimalkan penerimaan dengan selalu tercapainya target yang ditentukan dengan realisasi yang dihasilkan.

Sedangkan untuk tingkat efektifitas PNBP di TNBB, berdasarkan hasil penelitian tahun 2012 berada pada tingkatan yang sangat efektif, begitupun pada tahun 2013. Kemudian tahun 2014 tingkat efektifitas pada gambar tersebut memperlihatkan keefektifan yang meningkat juga. Sedangkan pada tahun 2015 terjadi lonjakan yang sangat signifikan, hal ini dikarenakan pada tahun 2015 telah menerapkan seluruhnya ketentuan PP No.12 Tahun 2014, sedangkan tahun 2014 belum sepenuhnya diterapkan PP No.12 Tahun 2014 yang baru di mulai pada bulan Juli 2014, antara lain tamu mancanegara sebesar Rp. 250.000 per orang, sedangkan Januari s.d Juni menggunakan tarif sebelumnya dengan tarif sebesar Rp. 20.000. Selanjutnya pada tahun 2016 terjadi penurunan dibandingkan tahun 2015 dikarenakan penetapan target oleh Pemerintah Pusat tahun 2015 lebih rendah dibandingkan target tahun 2016.

\section{Simpulan}

Peraturan Pemerintah Nomor 12 Tahun 2014 menjadi alat pengendali internal terhadap PNBP di Taman Nasional Bali Barat. Keakuratan pencatatan PNBP di Taman Nasional Bali Barat didasarkan pada penetapan tarif berdasarkan Peraturan Pemerintah Nomor 12 Tahun 2014 tentang Tarif atas Jenis PNBP yang berlaku pada Kementerian Kehutanan. Untuk kepatuhan pengelolaan PNBP di Taman Nasional Bali Barat didasarkan pada Peraturan Pemerintah Nomor 20 Tahun 1997 tentang Penerimaan Negara Bukan Pajak. Kemudian untuk tingkat keefektifan PNBP di Taman Nasional Bali, dengan perolehan persentase keefektifan $>100 \%$ pada setiap tahunnya, berdasarkan standarisasi disimpulkan bahwa dalam lima tahun tersebut Penerimaan Negara Bukan Pajak (PNBP) di Taman Nasional Bali Barat sangat efektif.

Adapun saran yang dapat diuraikan berdasarkan penelitian yang dilakukan yaitu, penelitian selanjutnya diharapkan agar lebih memahami serta memperoleh informasi lebih rinci terkait kondisi yang mempengaruhi tingkat efektivitas Penerimaan Negara Bukan Pajak (PNBP). Penjelasan dan pembahasan yang lebih rinci akan memberikan informasi yang lengkap sehingga pemahaman kondisi efektivitas Penerimaan Negara Bukan Pajak (PNBP) tersebut lebih baik.

\section{Referensi}

Agus, Eko Budiyanto. 2004. Strategi Peningkatan Pajak Daerah (Tinjauan Teoritis Terhadap Kebijakan Pemerintah Kabupaten/Kota Dalam Peningkatan Pajak Daerah). Dalam Halim (Ed.), Bunga Rampai Manajemen Keuangan Daerah (127-140). Edisi Revisi. Yogyakarta: UPP AMP YKPN.

Natalia, Ria. 2012. "Pengendalian Internal Terhadap Penerimaan Negara Bukan Pajak (PNBP) Melalui Penerapan Peraturan Pemerintah No 9 Tahun 2012 pada Direktorat Jenderal Mineral dan Batu Bara Jakarta", digilib.esaunggul.ac.id.

Republik Indonesia. 1997. Undang-undang Republik Indonesia Nomor 20 Tahun 1997 Tentang Penerimaan Negara Bukan Pajak.

Republik Indonesia. 2003. Undang-undang Republik Indonesia Nomor 17 Tahun 2003 Tentang Keuangan Negara.

Republik Indonesia. 1999. Peraturan Pemerintah Nomor 73 Tentang Tata Cara Penggunaan Penerimaan Negara Bukan Pajak yang Bersumber Dari Kegiatan Tertentu.

Republik Indonesia. 2008. Peraturan Pemerintah Republik Indonesia Nomor 60 Tahun 2008 Tentang Sistem Pengendalian Internal Pemerintah.

Republik Indonesia. 2014. Peraturan Pemerintah Republik Indonesia Nomor 12 Tahun 2014 Tentang Tarif atas Jenis Penerimaan Negara Bukan Pajak yang Berlaku Pada Kementerian Kehutanan.

Sanusi. 2011. Metode Penelitian Bisnis. Jakarta: Salemba Empat.

Sidjabat, Samuel. 2009. "Pengendalian Internal Terhadap Penerimaan Negara Bukan Pajak (PNBP) Melalui Penerapan Peraturan Pemerintah Republik Indonesia Nomor 46 Tahun 2002 Pada Kantor Wilayah Badan Pertanahan Nasional (BPN)", repository.usu.ac.id.

Sugiyono. 2012. Metode Penelitian Kualitatif. Bandung: Alfabeta.

Syamni, Ghazali. 2008. Analisis dan Efektifitas Komponen Pendapatan Asli Daerah Terhadap Anggaran Pendapatan Belanja Daerah. http://khairilanwarsamsi.blogspot.com/2012/01/analisis-kontribusidan-efektifitas.html.

Untara, G.D. et al. 2015. Statistik Balai Taman Nasional Bali Barat Tahun 2015. Jembrana: TNBB.

Yuliyanti, Eli. 2014. "Analisis Efektivitas dan Kontribusi Pendapatan Negara Bukan Pajak (PNBP) Pada Fakultas di Universitas Bengkulu", repository.unib.ac.id. 